\title{
NUTRITIONAL EDUCATION THROUGH RECREATIONAL ACTIVITIES AS AN ENTERTAINMENT TOOL IN HOTEL BUSINESSES
}

\author{
Priscila Fernandes Carvalho de Meloa; \\ Edilaine da Silva Motab; \\ Patrícia Pinheiro Fernandes Vieirac
}

\begin{abstract}
Food, with its different flavors, is introduced into a child's life by the family and through nutritional education. Recreational activities also give children the ability to understand what to eat, and how to eat it. Due to the high demand for tourist accommodation that focuses on the family segment, the tourist trade, particularly hotel business, is hiring more employees in the recreation and leisure sector, in order to assist children and parents who want to enjoy a few hours of carefree leisure and rest. This article aims to show that recreational activities that provide nutritional education can be developed by hotel businesses as a form of children's entertainment, stimulating creativity, teamwork, imagination, interpersonal relationships, the comfort of parents, along with an improvement in dietary habits. This study involves applied, exploratory, descriptive and bibliographic research, with a quantitative analysis to evaluate the level of children's satisfaction, using a visual 3-point Likert Scale. As an action strategy, we organized lectures with fun activities. We conclude that activities associated with nutritional learning are accepted by children as a means of socialization and entertainment, making them tools for use in accommodation establishments, as a recreational activity aimed at encouraging healthy eating.
\end{abstract}

\section{Palavras-chave}

Hotel business

Recreational activities

Nutritional education

Entertainment 


\section{INTRODUCTION}

Recreational and leisure services offered to guests by the hotel sector are among the main services enjoyed by children, and when offered with quality, can determine the success of an enterprise (KUSHANO, 2008).

The tourist trade, especially hotel businesses, needs to pay close attention to the family segment, as having younger children, in particular, is considered to influence the parents' decision-making when it comes to choosing tourism products and services (COOPER, 2001).

To ensure a successful holiday, parents with young children often look for leisure hotels or resorts that have recreational spaces where the children can be entertained, while the adults relax or do other activities. Hotel businesses therefore rely on professionals with training in the recreation and leisure sector; qualified people who can offer activities to develop children's motor and cognitive abilities, through roleplay for example, and promote social interaction among the children.

According to Albiero \& Alves (2007, pp. 17-21), children need a balanced diet, with nutrients that will promote cognitive and psychomotor development. It is during childhood that dietary habits are formed and consolidated, hence the importance of nutritional education strategies designed for children, with the aim of promoting health (COSTA, 2004).

To meet the needs of the tourism industry on one hand, and on the other, the desires and expectations of a tourist segment - families, who seek leisure, rest and to be entertained, the question arises: can nutritional education aimed at children through recreational activities be used as an entertainment tool in hotel businesses?

Based on this question, this research aims to demonstrate that recreational activities focused on nutritional education can be developed in hotel businesses as an entertainment tool for children, stimulating creativity, teamwork, imagination, social interaction, and parental comfort.

\section{THEORETICAL FRAMEWORK}

Nutritional education can be used as an instrument to help individuals organize their diets. For Fagioli and Nasser (2006, p. 244) nutritional education is "a variety of planned experiences that promote the voluntary adoption of eating habits or any behavior related to eating, which leads to health and wellbeing".

Analyzing this statement, we see that this instruction directly influences the development and continuation of healthy eating habits, informing people about proper nutrition. Healthy eating habits are essential for every stage of life, as they contribute to all stages in the growth and physiological development of the human being, as well as the maintenance of health and well-being.

Food, with its many flavors, is introduced to children by their families. From the moment children learn about the nutritional value of food, and understand its importance, it becomes easier to change their eating habits as they are growing up.

The sooner this critical sense is introduced into children's lives, the sooner it will begin to have positive effects on their development. Another benefit of this education is that it gives provides an opportunity to include friends, family and the school community in the whole process of forming and consolidating habits (JUZWIAK, CASTRO, \& BATISTA, 2013). Education on diet and nutrition takes place over a long period, intervening in culture and attitudes with cognitive bases (CERVATO, 2005).

Education through recreational activities promotes physical, motor, emotional, cognitive, and social development in children. It also provides leisure and social interaction while learning, in a friendly and challenging environment with plenty of opportunities for intellectual growth.

But games and play have not always been viewed in a favorable light, and such activities have not always been part of traditional school activities. It was only at the beginning of the 20th century, with the expansion of new teaching ideals, that such activities became more commonplace in Education, with the aim of facilitating learning. Care should be taken not to use games and play to excess, and to ensure that the focus is always on education (KISHIMOTO, 2016). Based on this premise, games can instill in children a sense of pleasure, freedom, notions of rules, and imagination. Children have access to many traditional games that aim to broaden their social interaction, and others that can be modified by adding new content (KISHIMOTO, 2016, p. 25).

Such games encourage children to become involved in a fantasy world, to learn how to deal with conflicts, and fulfill their desires. However, as the child grows older, the games and play activities assume more real characteristics (PIAGET, 1978). Brougère (2008) states that these activities evoke to the meaning of ordinary life, but with another meaning: fantasy or make-believe. There are countless activities that can be offered to children, such as singing in rounds, cooking workshops, ball games, and playing musical instruments. Some activities develop cultural awareness, such as Brazilian capoeira. There is drawing, modeling with playdough, and educational games that provide motor and cognitive development and socialization. The tourism trade has offered new proposals focused 
on children. These are discussed by Swarbrooke (2002, p. 408) as an emerging theme in tourism. Such programs developed for children should contain, wherever possible, activities that develop cultural learning and pedagogical practices (STOPPA, 1999, p. 100), and that provide a playful environment capable of developing children's creativity and joy. (MARCELLINO, 2006).

Negrine, Bradacz and Carvalho (2001) state that activities should be developed according to age group, so that children can better enjoy these moments. Also according to these authors, activities during children's' meal times are interesting for many stages of childhood, as well as providing parents with moments of relaxation during the meal.

To enable parents to enjoy a few hours of uninterrupted leisure time, many hotels, especially resorts and leisure hotels, are hiring more employees with training in recreation and leisure, as when it comes to choosing a hotel, parents' decisions are often influenced by the availability of children's' activities. When the children are busy, the parents can relax.

Families going on holiday are looking for something different that will meet their needs. Thus, to ensure competitive advantage, hotels are looking for alternatives that will help them stand out in the market (WAINBERG, 1998). One such alternative is to offer ways of providing satisfaction for all interested parties (KRIPPENDORF, 2000).

In view of the possibilities and wide variety of activities that can be offered to children to promote their development, we see an opportunity to offer games that will help children understand more about healthy eating, through activities that are both entertaining and educational.

\section{METHODOLOGY}

The project "Popular Education: recreational strategies in Nutritional Education to improve the eating habits of elementary school children in municipal schools of João Pessoa" is part of an extension program of the Federal University of Paraíba (UFPB) in that city. The program seeks to provide undergraduate students with opportunities to identify the possible needs and demands of society, and to act to meet them.

The project aims to promote and develop healthy eating habits in elementary school children in the municipal schools of João Pessoa, through play activities that teach nutritional education based on recreation and leisure. The activities are conducted by students of the Hotel Management and Gastronomy course.

This study uses applied, exploratory, descriptive and bibliographic research, with a quantitative analysis. We began by analyzing the available literature on the topic, including national and international scientific arti- cles cited in the CAPES and Google Scholar databases, on the following themes: hospitality, recreational activities, nutritional education and entertainment.

The purpose of exploratory research is to gain a better understanding of the proposed theme from a deeper perspective (MALHOTRA, 2011). It can be used for current or future research, as a secondary database. The university students therefore visited some municipal schools, seeking to understand how recreational activities are carried out there. and how they are applied in the classroom with elementary school pupils.

For this research, we used primary data from visits in loco to municipal schools, to learn how teachers and pupils relate to play activities; we also used external secondary data, based on scientific articles and books obtained from reliable search platforms, such as the CAPES and Google Scholar databases. According to Malhotra (2011), secondary data has the advantage over primary data that it can be collected more quickly and easily.

Descriptive research interprets the reality without the intention of modifying it (CHURCHILL, 1987), i.e. the sole purpose is to observe the phenomena, in order to later describe them. We therefore sought, through play workshops, to transmit knowledge about healthy eating to the elementary school children. Afterwards, we evaluated the application of recreational activities as an entertainment tool in accommodation establishments. At this time, talks were given in the courts and classrooms of the school, with the support of the teachers, the school principals, and in some cases, special education teachers.

The applied nature of the research is evidenced by the fact that its results can generate opportunities for implementing entertainment strategies in hotels.

Given that this research is quantitative, in order to carry out the analysis from an empirical point of view we elaborated a survey questionnaire, as a data collection instrument aimed at evaluating the children's' level of satisfaction with the proposed activities, through a visual 3-point Likert Scale. We also applied a questionnaire with objective and subjective questions about the instructors (students of the Hotel Management course), which was applied to the teachers, principals and special education teachers, during the lecture on the play activity. The action strategies carried out were recreational activities.

Before the lectures and the questionnaire, we carried out a pre-test with twenty-five students in the first semester of the Hotel Management course at the Federal University of Paraíba, to check for possible errors in the talks and in the application of the questionnaire.

From May to November of 2018, we gave seven talks on healthy eating and ran a practical workshop for 
252 elementary school children aged between six and seven years old. The project included seven municipal schools, in the neighborhoods of Grotão, Colinas do Sul, Gramame and Bancários. The age range of six to seven years was chosen for these activities because this is the period when children start reading in municipal schools, which would enable them to understand the information better, in order to achieve the planned objectives.

The research sample was non-probabilistic and was based on a selection by non-random methods, with the schools being selected according to the availability of students and teachers from institutions that showed interest in being part of the project (WALLIMAN, 2015). The data collected, according to Marconi and Lakatos (2003), must be analyzed and interpreted based on selection, coding and tabulation of the data, whether manually or mechanically.

The collected data were checked for possible errors or flaws that could compromise the research. Next, the data were tabulated using the Officer program and a statistical method. For a better understanding of the methodological path taken to achieve the objectives proposed, we have prepared a flowchart, as follows:

Figure 01 - Methodological flowchart

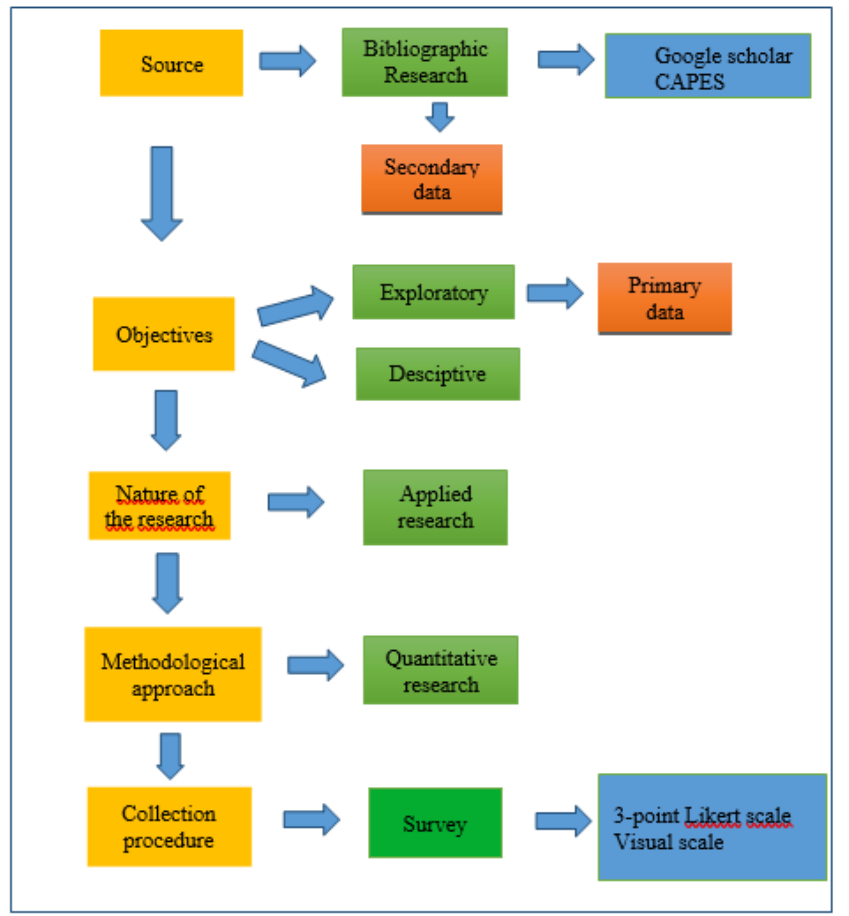

Source: prepared by the authors, 2019.

\section{RESULTS AND DISCUSSIONS}

The exploratory and bibliographic research led us to select different types of recreational activities to be applied to elementary school children in João Pessoa. However, due to the conditions in some of the schools, it was necessary to adapt the activities to help this audience and their needs.

One of the actions carried out was a brief play focusing on the story of a child who was celebrating her birthday. First, she announces that she hopes to eat cake all day. Then a second character, "a nutritionist", enters and introduces the content to all the children using a food pyramid as a visual tool. During the explanation, members of the audience are randomly picked, and invited to come and stick items of food on the pyramid, in their correct categories. When the pyramid is complete, the children are invited to review all they have learned, in order to check what they have remembered.

\section{Figure 02 - Food pyramid play activity}

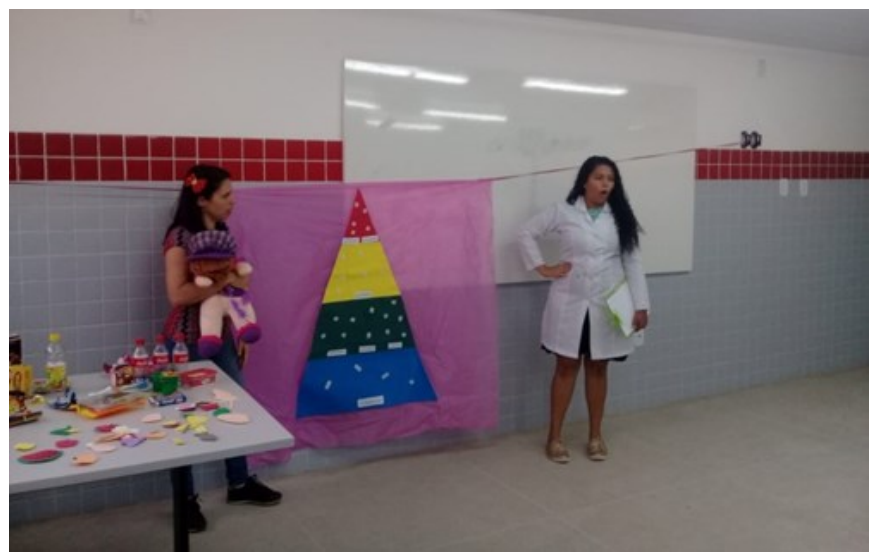

Source: Research data, 2018.

The second activity is called "At the market with friends". Two children are invited to make an imaginary purchase. Each child receives a bag, one with a happy face on it, in which they place food items that can be consumed in large quantities; and a second bag with a sad face, in which they place food items that should be consumed in smaller quantities. At the end of the shopping roleplay, the children analyze the items in the two bags. 
Figure 03 - Costume change

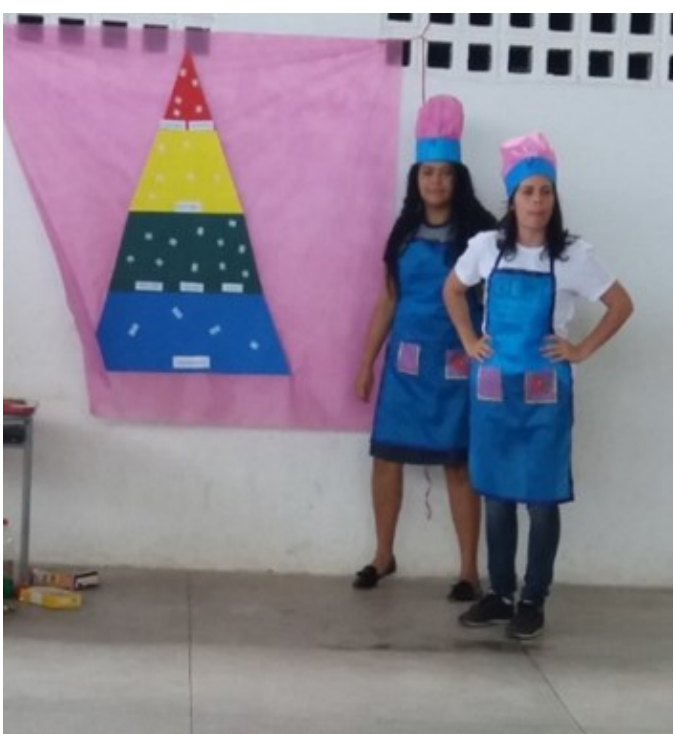

Source: Research data, 2018.

Figure 04 - Activity: At the market with friends

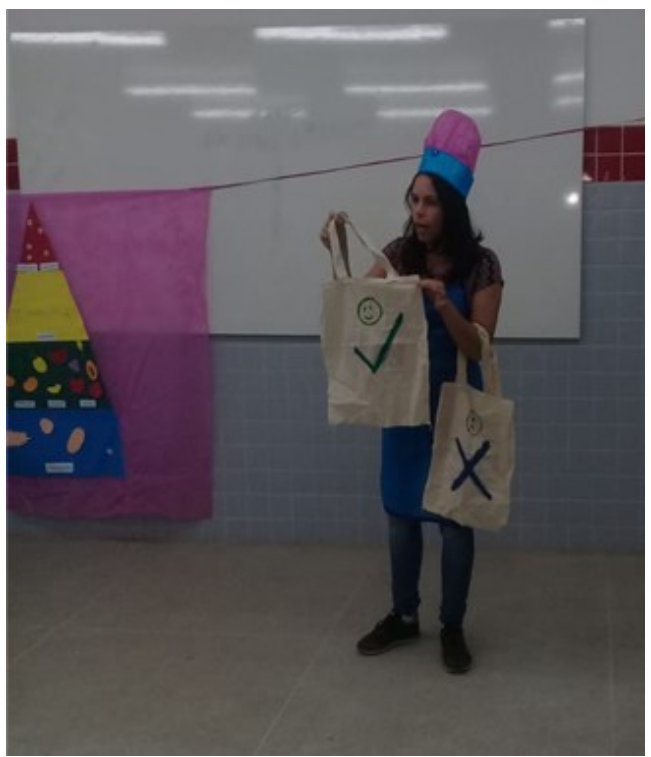

Source: Research data, 2018.

Finally, a sensory challenge is carried out: nine children are invited to the front, three at a time. They are blindfolded, and asked to determine what foods are being offered using their senses of touch, taste and smell.
Figure 05 - Sensory challenge

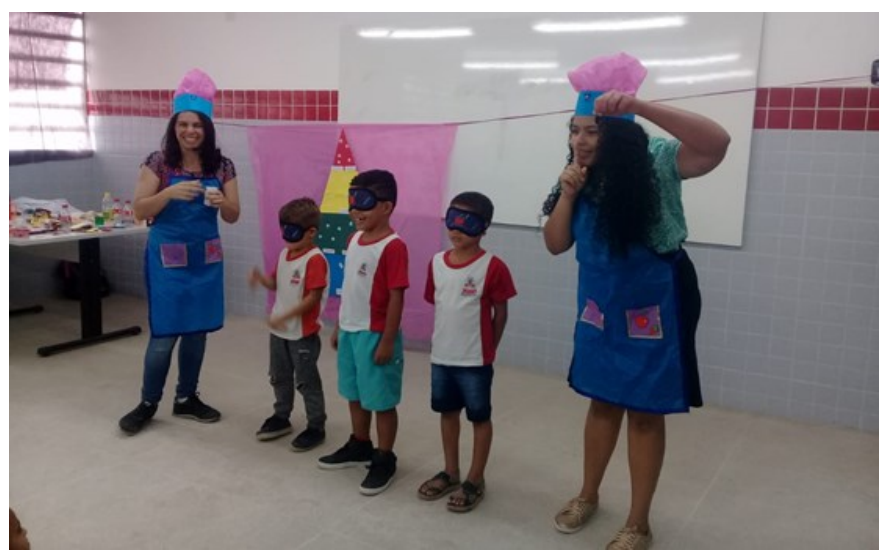

Source: Research data, 2018.

To assess the pupils' level of satisfaction, the college students applied a questionnaire at the end of the activities, using a visual 3-point Likert scale, with a percentage of $89 \%$ satisfaction representing Very good; $4 \%$ Fair; and 7\% Poor; emphasizing attitudes of gratitude and recognition at the end of the game.

Figure 06 - Visual scale: "Did you like it?"

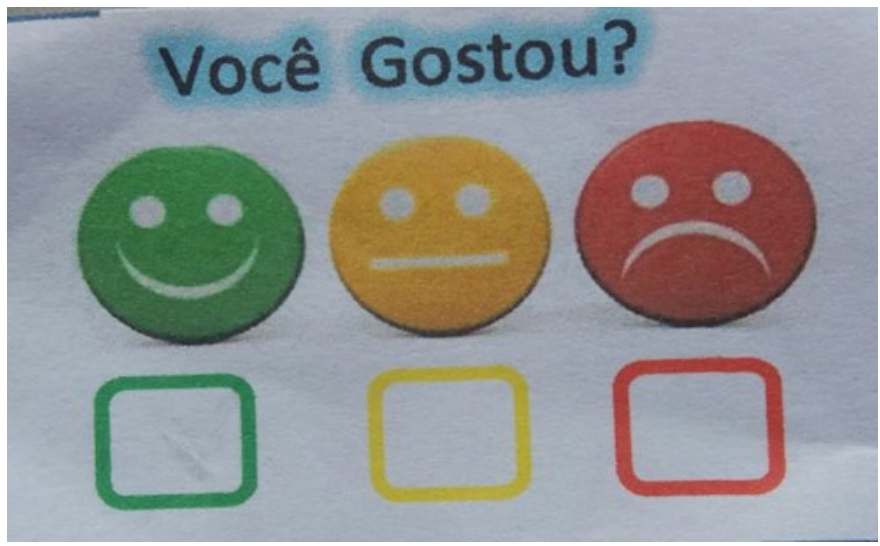

Source: Research data, 2018.

We also evaluated the project from the teachers' perspective, through a semi-structured questionnaire, obtaining scores of between 9 and 10 in all the schools covered in this stage of the project.

The assessment stage is important for observing and analyzing the level of satisfaction of the results: for the school, which opens its doors to integration between the university and society; for the children, who benefit from the different and playful strategies while learning; and finally for the college students involved, who are able to practice what they have learned in the subjects "Introduction to Food and Beverages" and "Recreation and Leisure", as part of the Hotel Management course, in addition to training a more dynamic professional with a more social perspective. 
After applying these activities in seven municipal schools of João Pessoa, the college students and their teachers chose one of the schools to apply the workshop. The purpose of this activity is to involve the children in the production of healthy food. The Lúcia Giovanna Municipal Elementary School, located in Gramame, was chosen, as it was the one with the best physical conditions and the highest number of students and teachers to participate.

To begin, the children were divided into five groups of ten pupils each, with the presence of a teacher to assist in the activities. Next, the instructors gave the instructions, and the groups started working together to produce a healthy Banana and cinnamon cake.

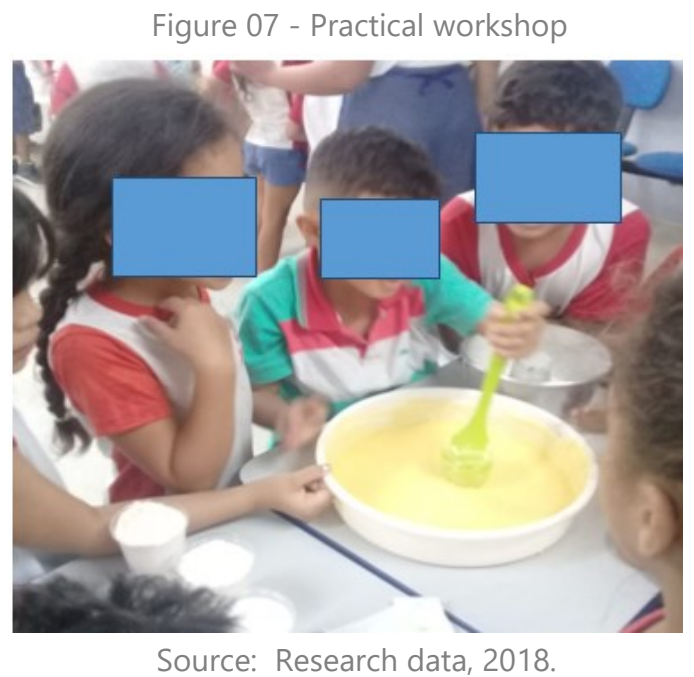

In addition to healthy eating, the workshop covered text and visual interpretation of all the procedures adopted, as well as notions of Math, thus addressing interdisciplinarity within the project.

\section{APPLICATION IN HOTELS}

Based on the results obtained in this research, we found that the play activities already carried out in hotels can become a factor of competitive advantage if other aspects are added, such as education, social interactions, companionship, empathy, healthy competitiveness and social inclusion.

These activities, when managed by a team of properly trained professionals, offer not only games as leisure activities, but also a creative way of providing knowledge to children and people in their social lives, as they are considered influential in parents' decisionmaking (COOPER, 2001).

Recreational activities involving nutritional issues enable children to make healthier food choices. However, we suggest that these actions take place at meal times, in order to encourage a healthier diet and offer parents a few moments of relaxation, being able to eat their meal in peace while seeing their children interacting with others and eating foods they wouldn't normally touch, such as vegetables.

As for the sensory analysis activity, we recommend this be carried out at breakfast, when hotels generally offer a variety of fruits, as this will help instigate the children's' curiosity, and senses of taste and smell.

This game, when properly managed, is fun for children, a comfort for parents and a success story for the hotel, as it provides knowledge and personal interrelation in a world where people communicate almost exclusively through social networks.

This is a low-cost tool, in other words, it uses materials that are already found in hotels, such as sticky tape, glue, paper, pencil, empty packaging, and food that is already available as part of the meals offered, so, these activities can be easily applied. However, one of the biggest challenges is finding professionals who are able to teach children a sense of responsibility, companionship, creativity, empathy, and inclusion.

\section{PRACTICAL AND/OR THEORE- TICAL IMPLICATIONS}

Though this study, it was clear that the elementary public schools in João Pessoa-PB support the integration between university and community, when seeking to disseminate knowledge, since all the campi visited requested that the project be applied again, as well as new projects, in order to explore the proposed theme in more depth. Thus, due to the good acceptance by the managers of the municipal schools, the project was renewed for 2019.

Thus, based on the project "Popular Education: recreational strategies in Nutritional Education to improve the eating habits of elementary school children in municipal schools of João Pessoa", we saw the impact of these activities, in terms of acquired knowledge and acceptance of new experiences. This practice contributes to our theories because play activities promote understanding, creativity and interpersonal relationships among children.

Associating gastronomy with play activities in the hotel business can create a new vision of activities for children, since it turns a play activity into an opportunity to learn more about how to promote good eating habits in children, while at the same time, giving the parents and the family moments of leisure, creating a threefold benefit that can be successfully explored by hotels. 


\section{CONCLUSIONS}

Through his project, we found that the play activities applied in the municipal schools with children aged from six to seven years can also be applied in hotel businesses, in the recreation and leisure sector. They are low in cost, and can be adapted to the needs of the sector, and accommodation establishments.

Materials such as EVA, cardboard, non-woven fabric, glue, empty food packaging, bags, and seasonal fruits can be used to develop play activities that will awaken children's curiosity to learn about good health, as well as promoting new dynamics and interpersonal relationships.

The project was extremely significant for those who conducted the activities in schools (i.e. students of the Hotel Management Course) as through them, they were able to associate the content studied in the classroom, in the disciplines of "Introduction to Food and Beverages" and "Recreation and Leisure". Also, the teachers at the schools where the activities took place were introduced to new teaching methods using recreational activities.

We therefore conclude that play activities can promote learning and incite children's' interest and concentration. These actions can be replicated in the hotel sector as an entertainment, leisure and education tool.

\section{REFERENCES}

ALBIERO, K. A., \& ALVES, F. (2007). Formação e desenvolvimento de hábitos alimentares em crianças pela educação nutricional. Revista nutrição em pauta, 15

Brougère, G. (2008). A criança e a cultura lúdica. Em T. M. Kishimotto, O Brincar e suas Teorias. São Paulo: Cengage Learning.

CASTELLI, G. (2000). ADMINISTRAÇÃO HOTELEIRA (6 ed.). EDUCS.

CERVATO, M. A. (2005). Educação nutricional para o ensino fundamental. Revista de nutrição, 18(5), 661-667.

CHURCHILL, J. (1987). Marketing research: methodological foundations. Chicago: The Dryden Press.

COOPER, C. e. (2001). Turismo: Priscípios e práticas. Porto Alegre: Bookman.

COSTA, A. G. (Julho/Agosto de 2004). Aplicação de jogo educativo para promoção da educação nutricional de crianças e adolescentes. Revista nutrição Brasil, 3, 205-209.

FAGIOLI, D., \& NASSER, L. (2006). Educação nutrivional na infância e na adolescência: planejamento, intervenção, avaliação e dinâmicas. São Paulo: RCN
GIL, C. A. (2002). Como elaborar projetos de pesquisa (4 ed.). São Paulo: Atlas

JUZWIAK, C. R., CASTRO, P. \& BATISTA, S. (2013). A experiência da oficina permanente de educação e em saúde (OPEAS): formação profissional para a promoção da alimentação saudável nas escolas. Ciência \& Saúde coletiva, 1009 1018.

KISHIMOTO, T. M. (2016). O jogo e a Educação Infantil.São Paulo: Cengage Learning.

KRIPPENDORF, J. (2000). Sociologia do turismo: para uma nova compreensão do lazer e das viagens. São Paulo: Aleph.

KUSHANO, E. S. (2008). Adequação de produtos e serviços tutísticos para as crianças: um olhar para os meios de hospedagem. Ilhéus, Bahia.

MALHOTRA, N. K. (2011). Pesquisa de Marketing (6 ed.). Bookman.

MARCELLINO, C. N. (2006). Estudos do lazer - uma introdução (4 ed.). Campinas.

MARCONI, M. d., \& LAKATOS, E. (2003). Fundamentos da metodologia Científica (5 ed.). São Paulo: Atlas.

NEGRINE, A., BRADACZ, L., \& CARVALHO, P. (2001). Recreação na Hotelaria: o pensar e o fazer lúdico. Caxias do Sul: EDUCS.

PIAGET, J. (1978). A formação do símbolo na criança. Rio de Janeiro: Zahar.

STOPPA, E. A. (1999). Acampamentos de férias. Campinas: Papirus.

SWARBROOKE, J. (2002). O COMPORTAMENTO DO CONSUMIDOR NO TURISMO. (S. Krieger, Trad.) São Paulo: Aleph.

THIOLLENT, M. (1992). Metodologia da pesquisa - Ação. São Paulo: Cortez.

WAINBERG, J. (1998). aNOTAÇÕES PARA UMA TEORIA DO TURISMO: A INDÚSTRIA DA DIFERENÇA. Porto Alegre: GASTAL.

WALLIMAN, N. (2015). Métodos de pesquisa. São Paulo: Saraiva. 